\title{
SPATIAL AND TEMPORAL DISTRIBUTION OF BENTHIC MACROINVERTEBRATES IN A SOUTHEASTERN BRAZILIAN RIVER
}

\author{
SILVEIRA, M. P. ${ }^{1}$, BUSS, D. F. ${ }^{2}$, NESSIMIAN, J. L. ${ }^{3}$ and BAPTISTA, D. F. ${ }^{2}$ \\ ${ }^{1}$ Embrapa Environment, Rodovia SP 340, Km 127.5, C. P. 69, CEP 13820-000, Jaguariúna, São Paulo, Brazil \\ ${ }^{2}$ Departamento de Biologia, IOC, Fiocruz, Av. Brasil, 4365, CEP 21045-900, Manguinhos, Rio de Janeiro, Brazil \\ ${ }^{3}$ Laboratório de Entomologia, Departamento de Biologia, CCS, UFRJ, C. P. 68044, CEP 21944-970, \\ Ilha do Fundão, Rio de Janeiro, Brazil \\ Correspondence to: Mariana Pinheiro Silveira, Embrapa Environment, Rodovia SP 340, Km 127.5, \\ C. P. 69, CEP 13820-000, Jaguariúna, São Paulo, Brazil
}

Received June 7, 2004 - Accepted September 24, 2004 - Distributed May 31, 2006

(With 4 figures)

\begin{abstract}
Benthic macroinvertebrate assemblages are structured according to physical and chemical parameters that define microhabitats, including food supply, shelter to escape predators, and other biological parameters that influence reproductive success. The aim of this study is to investigate spatial and temporal distribution of macroinvertebrate assemblages at the Macaé river basin, in Rio de Janeiro state, Southeastern Brazil. According to the "Habitat Assessment Field Data Sheet - High Gradient Streams" (Barbour et al., 1999), the five sampling sites are considered as a reference condition. Despite the differences in hydrological parameters (mean width, depth and discharge) among sites, the physicochemical parameters and functional feeding groups' general structure were similar, except for the less impacted area, which showed more shredders. According to the Detrended Correspondence Analysis based on substrates, there is a clear distinction between pool and riffle assemblages. In fact, the riffle litter substrate had higher taxa in terms of richness and abundance, but the pool litter substrate had the greatest number of exclusive taxa. A Cluster Analysis based on sampling sites data showed that temporal variation was the main factor in structuring macroinvertebrate assemblages in the studied habitats.
\end{abstract}

Keywords: benthic macroinvertebrates, Southeastern Brazil, substrates, distribution.

\section{RESUMO}

\section{Distribuição espaço-temporal de macroinvertebrados bentônicos em um rio do sudeste brasileiro}

A fauna de macroinvertebrados bentônicos é estruturada por fatores físicos e químicos que determinam os microhábitats, incluindo a disponibilidade de alimento, a existência de refúgios contra predadores e tempestades, o sucesso reprodutivo e outros parâmetros biológicos. O objetivo deste estudo foi investigar a distribuição espaço-temporal da comunidade de macroinvertebrados bentônicos na bacia do rio Macaé, Estado do Rio de Janeiro, Brasil. De acordo com o Habitat Assessment Field Data Sheet - High Gradient Streams (Barbour et al., 1999), os cinco locais coletados são considerados como referência para propósito de biomonitoramento. Apesar das diferenças em parâmetros hidrográficos (largura, profundidade e vazão médias), os parâmetros físico-químicos e a composição dos grupos de alimentação funcional foram similares entre os locais, com exceção da área mais preservada, onde a porcentagem de organismos cortadores foi maior. De acordo com a Análise de Correspondência, há uma clara distinção entre áreas de remanso e de correnteza. De fato, o substrato folhiço de correnteza apresentou a fauna mais rica e abundante, enquanto o substrato folhiço de fundo apresentou o maior número de táxons exclusivos. A Análise de Agrupamento 
considerando os dados dos locais de coleta indicou que a variação temporal foi o fator mais importante na estruturação das comunidades nos hábitats estudados.

Palavras-chave: macroinvertebrados bentônicos, sudeste brasileiro, substratos, distribuição.

\section{INTRODUCTION}

The distributional pattern of aquatic organisms results from interaction among geomorphology of the stream bed (Wallace \& Webster, 1996), land-use (Resh et al., 1988), substrate type (Buss et al., 2004), hydraulic conditions (Statzner et al., 1988), water temperature (Merritt \& Cummins, 1996; Townsend et al., 1997) and biological interactions.

Jowett (1997) suggests that the generic term "habitat" should be used to describe the physical and chemical components of the stream, which provide the ideal environment for biota colonization.

Brown \& Brussock (1991) emphasize that despite the obvious differences in water flow, depth and slope between pools and riffles, other less obvious factors (like substrate composition) may also have pervasive influence on their suitability as habitats for macroinvertebrate species. Factors like the size of the particles (coarse or fine), conditions of refuges and the frequency, severity and intensity of disturbances are also critical for macroinvertebrate colonization.

The riparian zone is also an important factor for the perfect functioning of the river's ecosystem, because it provides food and shelter for the aquatic biota (Bretschko \& Moser, 1993). When considering the stream itself, the riparian zone modifies the microclimate (light, temperature and humidity), alters the flow of nutrients, forms the surrounding hillslopes, contributes with organic matter to the stream (from large, woody debris to small particulate matter), and strongly influences the ability of the stream to retain what it receives in any particular reach (Gregory et al., 1991).

According to the river Continuum Concept (RCC; Vannote et al., 1980), the aquatic macroinvertebrate fauna responds to the physical changes along the river longitudinal gradient. According to the RCC, shredders would be concentrated in headwater sections, since they are highly dependent on allocthonous organic matter from the riparian zone. In medium size rivers, the dominant macroinvertebrate functional feeding group is represented by scrapers due to decreasing detritus particle size and increasing algae primary production. Therefore, the river changes from an allocthonus input to an autochtonous situation, and there would be an ecotone in medium size rivers $\left(4^{\text {th }}\right.$ to $6^{\text {th }}$ order), with different colonizer species. In the lower river reaches, collectors achieve their greatest dominance and other groups become relatively rare. Although a greater species richness and diversity is expected in mid-order streams, tributaries can modify this pattern and the relation of richness and diversity vs. stream order, is not always evident (Bruns et al., 1984; Naiman et al., 1988).

The aim of this study is to define the macroinvertebrate fauna and its spatial and temporal distribution along the longitudinal gradient of the Sana river, a tributary of the Macaé river watershed in Rio de Janeiro state, Brazil.

\section{MATERIAL AND METHODS}

The Macaé river is located in an Atlantic Forest area in Rio de Janeiro state, Brazil ( $22^{\circ} 21^{\prime}-22^{\circ} 28^{\prime}$ $\mathrm{S}$ and $\left.42^{\circ} 27^{\prime}-42^{\circ} 35^{\prime} \mathrm{W}\right)$. Headwaters are at about 1,500 m.a.s.l. and the river runs through $110 \mathrm{~km}$ before reaching the Atlantic Ocean as a sixth order river. Further description may be found in Baptista et al. (2001).

In this study, five sites were sampled along the longitudinal gradient of the Sana river, in the low region of the Macaé river basin, between 420 and $160 \mathrm{~m}$ above sea level (Fig. 1). Sites were chosen in order to represent a natural longitudinal gradient, therefore, they should be similar in ecological as well as physicochemical parameters. Three other sites were sampled, but were excluded from this article since there was obvious impairment (one site) or were at higher altitudes (two sites).

A Surber sampler $\left(0.09 \mathrm{~m}^{2}\right.$ area, mesh size $125 \mu \mathrm{m}$ ) was used to collect three pseudo-replicates of four substrate types (stones and riffle litter in riffle areas, sediment and pool litter at pool areas) at each sampling site. The three samples of each substrate were then combined, forming four composite samples per site per sampling occasion. Samplings were taken in April (wet season), August (dry 


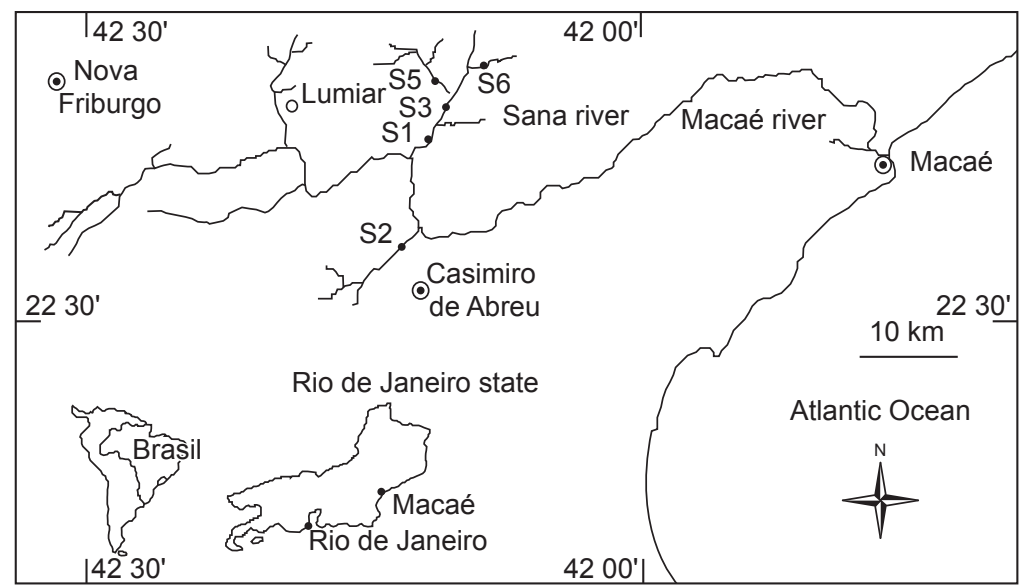

Fig. 1 - Map of the Sana river, in Macaé river watershed (Southern Brazil), indicating the five sampled sites.

season) 1999 and February (wet season) 2000. Due to difficulties in finding a preserved area, site S2 was only sampled twice (August 1999 and February 2000). Samples were packed in plastic bags and stored in $70 \%$ ethanol. At the laboratory, samples were rinsed through a $125 \mu \mathrm{m}$ mesh sieve and sorted under a stereomicroscope. Macroinvertebrates were identified in terms of the lowest taxonomic level using the available taxonomic keys: Angrisano (1995), Merritt \& Cummins (1996), Nieser \& de Melo (1997), and Carvalho \& Calil (2000). The Operational Taxonomic Unit (OTU) system was used in all the data analysis. Each time a biological sample was taken, field measurements of water depth, stream width, water current, $\mathrm{pH}$ (Corning PS-15 pHmeter), water temperature $\left({ }^{\circ} \mathrm{C}\right)$, dissolved oxygen and oxygen saturation (both using a $\mathrm{La}$ Motte $^{\circledR}$ oximeter) were recorded. The "Habitat Assessment Field Data Sheet - High Gradient Streams" (Barbour et al., 1999) was used at each site to assess local ecological quality. Moreover, a sample of water was taken and frozen for laboratory analysis of each of the following physico-chemical parameters: total hardness, chloride, electric conductivity, total alkalinity; ammonia; nitrite; and orthophosphate. The reactive orthophosphate was measured by the phosphomolibidic method; the diazotation method was used for nitrite, and ammoniac nitrogen was measured by the blue indophenol method (Parsons et al., 1984).

\section{Data analysis}

Total richness (S), the Shannon diversity index $\left(\mathrm{H}^{\prime}\right)$ and the Pielou index $(\mathrm{J})$ were measured for each site. Macroinvertebrates were classified into functional feeding groups (FFG), based on Merrit \& Cummins (1996), Angrisano (1995) and Fernández \& Domínguez (2001). In some cases, it was impossible to assign a single FFG to a taxon, so the total number of specimens of the taxon was divided among the FFGs. The Detrended Correspondence Analysis (DCA) was used in order to evaluate the macroinvertebrate assemblage structure, considering the substrate types and stream orders. All data were $\log _{10}(x+1)$ transformed to achieve the condition of normality and homocedasticity of the data. Preference (frequency $>40 \%$ at one substrate) and exclusiveness of each taxa were analyzed in order to determine macroinvertebrate distribution in the substrates. The influence of temporal variation in the sampling sites was also investigated using a Cluster Analysis (Bray Curtis index; Ward's method).

\section{RESULTS}

\section{Physicochemical and environmental integrity parameters}

Since sites were chosen to represent a "natural" longitudinal gradient, physicochemical parameters were similar among sampling sites. According to the "Habitat Assessment Field Data Sheet - High Gradient Streams" (Barbour et al., 1999) all sites were considered as reference conditions for biomonitoring purposes: four sites (S1, S3, S5 and S6) were sub-optimal and one site (S2) was classified as optimal. Sites were different 
in hydrological parameters (mean width and depth, discharge) reflecting the longitudinal gradient of the Sana river basin (Table 1).

\section{Structure and composition of community at substrate type}

A total of 27,046 specimens were collected throughout the studied period, belonging to 91 macroinvertebrate taxa and 45 families. The highest species richness and abundance were found at the $3^{\text {rd }}$ order stream (S5) with 57 taxa in February (rainy season). Both diversity and evenness rates were highest at the fourth order river (S3) during the dry period: 2,834 and 0.744 , respectively. Considering the substrate type, the riffle litter had the highest total richness (79 taxa), followed by pool litter (76), stone (67) and sediment (32 taxa).
The frequency of macroinvertebrate assemblages at each sampling site varied according to stream order and substrate type. Riffle litter had a higher percentage of abundance at sites S6, $\mathrm{S} 5, \mathrm{~S} 3$ and in the dry period at site S2. At site S1 $\left(5^{\text {th }}\right.$ order $)$, stony substrates had a higher percentage of abundance (Table 2).

\section{Substrate preference}

Riffle substrates (riffle litter and stones) were preferred ( $>40 \%$ abundance at one substrate) by sixteen taxa, while the pool litter substrate presented the greatest number of exclusive taxa (10 taxa). Gyrinidae was the only taxa exclusive of sediment (Table 3). Generally, taxa associated with pool areas were leaf-case builders (Phylloicus) and Odonata genera (Argia, Haeterina, Elasmothemis,

TABLE 1

Mean values of hydrological and physicochemical parameters in the Sana river. Minimum and maximum values in brackets; nd- non-detectable value.

\begin{tabular}{|c|c|c|c|c|c|}
\hline Sites & S6 & S5 & S2 & S3 & S1 \\
\hline Mean width (m) & 7.00 & 14.00 & 4.00 & 11.67 & 15.00 \\
\hline Mean depth (m) & 0.07 & 0.23 & 0.17 & 0.47 & 0.56 \\
\hline Mean speed $(\mathrm{m} / \mathrm{s})$ & 0.33 & 0.51 & 0.33 & 0.47 & 0.49 \\
\hline Mean discharge $\left(\mathrm{m}^{3} / \mathrm{s}\right)$ & 0.19 & 1.70 & 0.22 & 2.55 & 4.71 \\
\hline Altitude (m.a.s.l.) & 420 & 320 & 180 & 280 & 160 \\
\hline Stream order & 1 & 3 & 3 & 4 & 5 \\
\hline EPA index score & $12(15-11)$ & $15(15-11)$ & $19(20-16)$ & $14(15-11)$ & $15(15-11)$ \\
\hline Hardness (mg..$\left.^{-1}\right)$ & $16.70(10-22)$ & $13.30(8-20)$ & 18.00 & $14.70(10-18)$ & $14.70(12-20)$ \\
\hline Ca hardness $\left(\mathrm{mg} \mathrm{CaCO} \cdot{ }^{1-1}\right)$ & $4.70(4-6)$ & $5.30(4-6)$ & 4.00 & $4.70(4-6)$ & $4.70(4-6)$ \\
\hline Mg hardness $\left(\mathrm{mg} . \mathrm{l}^{-1}\right)$ & $12.00(6-18)$ & $8.00(4-14)$ & 14.00 & $10.00(6-14)$ & $10.00(6-16)$ \\
\hline $\mathrm{Cl}-\left(\mathrm{mg} .1^{-1}\right)$ & $6.50(5.4-7.8)$ & $5.80(4.4-8.7)$ & 8.70 & $5.50(2.4-7.4)$ & $4.20(2.4-6.8)$ \\
\hline Dissolved oxygen $\left(\mathrm{mg} . \mathrm{l}^{-1}\right)$ & $7.80(7.6-7.9)$ & $8.70(7.9-9.5)$ & $7.00(6.1-7.8)$ & $7.60(7.5-7.7)$ & $7.40(6.1-8.3)$ \\
\hline Oxygen saturation (\%) & $\begin{array}{l}83.20 \\
(81.5-86)\end{array}$ & $\begin{array}{l}91.40 \\
(79-100)\end{array}$ & $\begin{array}{l}74.25 \\
(67.5-81)\end{array}$ & $82.60(81-84)$ & $\begin{array}{l}79.60 \\
(66.8-91.0)\end{array}$ \\
\hline Water temperature $\left({ }^{\circ} \mathrm{C}\right)$ & $\begin{array}{l}20.10 \\
(18.4-22)\end{array}$ & $\begin{array}{l}19.30 \\
(16.4-22.5)\end{array}$ & $\begin{array}{l}20.00 \\
(17.4-22.5)\end{array}$ & $20.20(18-23)$ & $20.30(19-22)$ \\
\hline $\mathrm{pH}$ & $7.00(6.7-7.4)$ & $7.30(7.2-7.5)$ & $7.80(7.0-8.5)$ & $7.30(7.1-7.4)$ & $7.40(7.3-7.5)$ \\
\hline Conductivity $\left(\mu \mathrm{S} . \mathrm{cm}^{-1}\right)$ & $13.60(7-21.3)$ & $\begin{array}{l}11.00 \\
(6.5-18.5)\end{array}$ & 17.00 & $12.70(6.5-18)$ & $12.30(7-17.5)$ \\
\hline Alkalinity $\left(\mathrm{mg} . \mathrm{l}^{-1}\right)$ & $\begin{array}{l}17.90 \\
(12.6-19.8)\end{array}$ & $10.80(9-12.7)$ & 7.30 & $10.80(9-12.6)$ & $\begin{array}{l}10.80 \\
(9.1-12.6)\end{array}$ \\
\hline $\mathrm{NH}_{4}-\mathrm{N}\left(\mathrm{mg} . \mathrm{l}^{-1}\right)$ & \begin{tabular}{|l|}
0.04 \\
$(0.01-0.05)$
\end{tabular} & $\begin{array}{l}0.02 \\
(0.01-0.03)\end{array}$ & 0.01 & $\begin{array}{l}0.04 \\
(0.01-0.06)\end{array}$ & $\begin{array}{l}0.04 \\
(0.01-.004)\end{array}$ \\
\hline $\mathrm{NO}_{3}-\mathrm{N}\left(\mathrm{mg} \cdot \mathrm{l}^{-1}\right)$ & $0.01-\mathrm{nd}$ & 0.00 - nd & 0.01 & $\begin{array}{l}0.01 \\
(0.0-0.01)\end{array}$ & $0.01-\mathrm{nd}$ \\
\hline $\mathrm{PO}_{4}-\mathrm{P}\left(\mathrm{mg} . \mathrm{l}^{-1}\right)$ & \begin{tabular}{|l|}
0.11 \\
$(0.06-0.14)$
\end{tabular} & $\begin{array}{l}0.04 \\
(0.03-0.0)\end{array}$ & 0.03 & $\begin{array}{l}0.07 \\
(0.04-0.12)\end{array}$ & $\begin{array}{l}0.02 \\
(0.01-0.03)\end{array}$ \\
\hline
\end{tabular}


Megapodagrionidae sp.). Ephemeroptera genera were abundant on stony substrates (Dactylobaetis, Pseudocloeon, Camelobaetidius, Baetodes), and free-living taxa associated with riffle areas were Leptonema, Corydalus and all plecopterans (Anacroneuria, Gripopteryx and Paragripopteryx).

\section{Functional feeding groups}

The collector-gatherer group $(\mathrm{Cg})$ was predominant at all sampling sites, reaching its maximum at site $\mathrm{S} 1(71.52 \%)$. The collector-filterers (Cf) were more abundant at site S5 (10.41\%). At site $\mathrm{S} 2$, most of the shredders were observed (Sh) with $5.84 \%$ of the total individuals. Scrapers $(\mathrm{Sc})$ and predators $(\mathrm{P})$ showed the highest abundance at the fourth stream reach (S3) with $25.41 \%$ and $13.89 \%$, respectively (Fig. 2).

\section{Detrended correspondence analysis}

The first axis (18.05\% of the variance) indicated that the substrate type was the most important factor structuring the macroinvertebrate community at the Sana river, regardless of the river order. DCA plot show pool substrates (pool litter and sediment) were clearly distinguished from riffle substrates (riffle litter and stone) (Fig. 3).

\section{Cluster analysis}

To analyze the influence of environmental variables when distributing macroinvertebrates on

TABLE 2

Percentage of the total abundance and richness numbers for each substrate type and site in the three sampling periods.

\begin{tabular}{|c|c|c|c|c|c|c|c|}
\hline \multirow[t]{2}{*}{ Sites } & & \multicolumn{2}{|c|}{ April } & \multicolumn{2}{|c|}{ August } & \multicolumn{2}{|c|}{ February } \\
\hline & Substrates & $\%$ & $\mathbf{S}$ & $\%$ & $\mathbf{S}$ & $\%$ & $\mathbf{S}$ \\
\hline \multirow[t]{6}{*}{ S6 } & Riffle Litter & 40.50 & 26 & 44.53 & 31 & 67.16 & 37 \\
\hline & Stone & 21.25 & 28 & 15.04 & 20 & 24.51 & 27 \\
\hline & Pool Litter & 33.58 & 33 & 35.25 & 30 & 4.13 & 21 \\
\hline & Sediment & 4.67 & 5 & 5.18 & 7 & 4.20 & 2 \\
\hline & $\mathrm{N}$ & 1.200 & - & 1.389 & - & 1.426 & - \\
\hline & Richness & - & 45 & - & 49 & - & 45 \\
\hline \multirow[t]{6}{*}{ S5 } & Riffle Litter & 42.97 & 29 & 60.59 & 29 & 44.41 & 37 \\
\hline & Stone & 35.99 & 26 & 21.76 & 30 & 30.53 & 32 \\
\hline & Pool Litter & 19.51 & 27 & 15.68 & 17 & 22.71 & 38 \\
\hline & Sediment & 1.52 & 4 & 1.97 & 9 & 2.34 & 10 \\
\hline & $\mathrm{N}$ & 988 & - & 1.216 & - & 2.263 & - \\
\hline & Richness & - & 45 & - & 45 & & 57 \\
\hline \multirow[t]{6}{*}{$\mathbf{S 2}$} & Riffle Litter & - & - & 59.43 & 34 & 31.32 & 34 \\
\hline & Stone & - & - & 12.80 & 28 & 17.07 & 32 \\
\hline & Pool Litter & - & - & 21.24 & 23 & 47.11 & 31 \\
\hline & Sediment & - & - & 6.54 & 18 & 4.50 & 9 \\
\hline & $\mathrm{N}$ & - & - & 1.466 & - & 2.267 & - \\
\hline & Richness & - & - & - & 54 & - & 54 \\
\hline \multirow[t]{6}{*}{ S3 } & Riffle Litter & 51.57 & 28 & 48.07 & 34 & 43.33 & 36 \\
\hline & Stone & 17.00 & 31 & 16.18 & 31 & 6.77 & 25 \\
\hline & Pool Litter & 31.29 & 32 & 33.68 & 32 & 48.41 & 39 \\
\hline & Sediment & 0.14 & 3 & 2.07 & 11 & 1.49 & 5 \\
\hline & $\mathrm{N}$ & 2.100 & - & 2.659 & - & 2.894 & - \\
\hline & Richness & - & 47 & - & 45 & - & 50 \\
\hline \multirow[t]{6}{*}{ S1 } & Riffle Litter & 29.47 & 36 & 33.29 & 26 & 36.16 & 31 \\
\hline & Stone & 65.32 & 42 & 54.65 & 39 & 52.19 & 34 \\
\hline & Pool Litter & 4.50 & 25 & 8.72 & 25 & 9.19 & 21 \\
\hline & Sediment & 0.71 & 9 & 3.34 & 14 & 2.45 & 7 \\
\hline & $\mathrm{N}$ & 3.644 & - & 2.396 & - & 1.138 & - \\
\hline & Richness & - & 54 & - & 54 & - & 43 \\
\hline
\end{tabular}


a local spatial scale, substrates were pooled per site at each sampling period. The Cluster Analysis at site samples show three major groups: the first group consisting of samples from sites S5 and S6 (with S2B sample); the second group was formed by samples taken during February; and the third group comprising the remaining samples of sites S1 and S3 (Fig. 4).

\section{Insect order distribution at substrates}

Plecoptera: Four taxa were identified at the Sana river basin. The abundance of Plecoptera was clearly concentrated at the riffle litter substrate, although there were also some individuals on stone and pool litter substrates. The genus Anacroneuria was dominant at all substrates, with $93 \%$ of the individuals collected in April (from 273 stoneflies), $87 \%$ in August (from 322 stoneflies) and 83\% in February (from 334 stoneflies).

Ephemeroptera: Sixteen taxa were found. The ephemeropterans were equally represented at stone, riffle litter and pool litter substrates. Leptohyphes was the dominant genus on the three sampling occasions, but at different substrates at each

TABLE 3

Exclusiveness and taxa preferences at sampled substrates in the Sana river.

(Preference means more than $\mathbf{4 0 \%}$ of frequency in the substrate type).

\begin{tabular}{|c|c|c|}
\hline Substrate & Exclusive Taxa & Preferences \\
\hline Sediment & Gyrinidae & \\
\hline Pool Litter & $\begin{array}{l}\text { Dixidae, Limnocoris, Argia, } \\
\text { Haeterina, Megapodagrionidae sp., } \\
\text { Marilia, Protoptila, Triplectides, } \\
\text { Oecetis, Limnephilidae sp. }\end{array}$ & $\begin{array}{l}\text { Oligochaeta, Phylloicus, } \\
\text { Nectopsyche, Macronema, } \\
\text { Elasmothemis, Hagenulopsis, } \\
\text { Farrodes, Baetidae sp., Culicidae, } \\
\text { Stenochironomus, Tanypodinae, } \\
\text { Ceratopogonidae, Rhagovelia }\end{array}$ \\
\hline Stone & $\begin{array}{l}\text { Gonielmis, Psephenus, } \\
\text { Dactylobaetis, Brechmorhoga, } \\
\text { Cyrnellus, Orthotrichia, } \\
\text { Ochrotrichia }\end{array}$ & $\begin{array}{l}\text { Helicopsyche, Smicridea, } \\
\text { Grumichella, Chimarra, Atopsyche, } \\
\text { Pseudocloeon, Camelobaetidius, } \\
\text { Baetodes, Psychodidae, Tipo 9, } \\
\text { Xenelmis, Hexanchorus }\end{array}$ \\
\hline Riffle Litter & $\begin{array}{l}\text { Staphylinidae, Paracloeodes, } \\
\text { Rivudiva minnantena, Hudsonema, } \\
\text { Gomphus, Erpetogomphus, } \\
\text { T. fluviatilis Acari, Collembola }\end{array}$ & $\begin{array}{l}\text { Corydalus, Leptonema, } \\
\text { Paragripopteryx, Gripopteryx, } \\
\text { Anacroneuria, Leptohyphes, } \\
\text { Lachlania, Hylister, Americabaetis, } \\
\text { Simuliidae, Empididae, } \\
\text { Orthocladinae, Lutrochidae, } \\
\text { Phanocerus, Macrelmis, Heterelmis }\end{array}$ \\
\hline
\end{tabular}

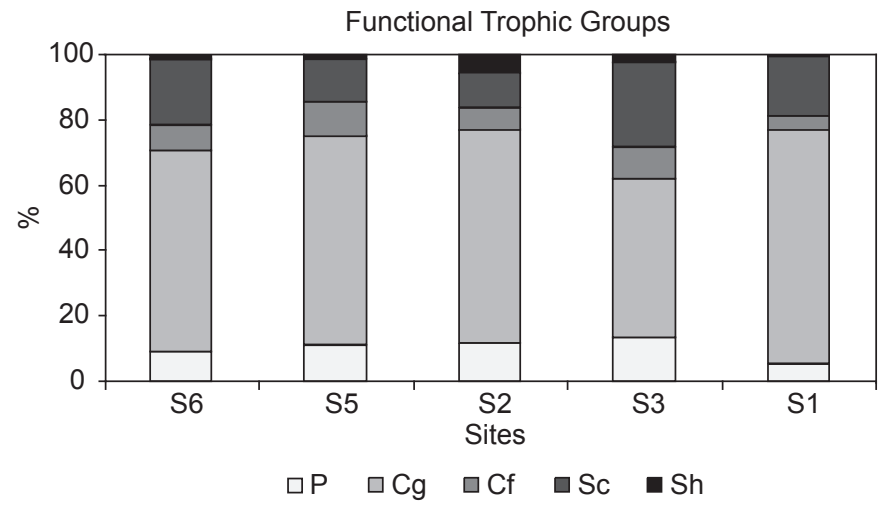

Fig. 2 - Proportion of Functional Trophic Groups at the Sana river. P - Predators; Cg - Collector-gatherers; Cf - Collectorfilterers; Sc - Scrapers; and Sh - Shredders. 
sampling occasion. In April, in a stony substrate, Leptohyphes represented $32 \%$ of all the mayfly community $(1,231$ individuals); in August, they represented $46 \%$ (from 988 specimens) of mayflies, mainly found in riffle litter; and in February, they represented $26 \%$ of the total ephemeropterans (1,822 individuals), and were dominant at the pool litter substrate.

Trichoptera: In this study, twenty genera of Trichoptera were found. As Ephemeroptera, the trichopterans were similarly represented at stone, riffle litter and pool litter substrates. Among them, the genus Smicridea was dominant in April and August, while Nectopsyche was the dominant genera in February. From all the caddisflies, Smicridea represented 59\% (a total of 832 individuals) in April and 51\% (a total of 720 specimens) in August, while Nectopsyche represented $34 \%$ of all sampled trichopterans in February (924 specimens).

Coleoptera: Seventeen taxa were found. The dominant genus throughout the whole study period was Heterelmis (Elmidae). The coleopterans were well represented at stone, riffle and pool litter substrates, but showed a strong preference for riffle litter, where many Elmidae genera were found. In April, this genus represented 62\% of all the coleopterans (1,962 individuals); in August, 60\% (from 2,160 coleopterans); and in February, this dominance increased to $70 \%$ (from 2,620 coleopterans). The genus Heterelmis was predominantly found in the pool litter during the rainy season (April and February) and in the riffle litter in August.

Odonata: In this study, ten Odonata genera were found. In general, Odonata were not abundant in our study. The dominant taxon varied on the three sampling occasions. In April, Elasmothemis and Brechmorhoga dominated the Odonatofauna with $32 \%$ and $34 \%$ (38 individuals), respectively; in August, Argia was the dominant genus, with 25\% of all individuals (56 specimens); and in February, Megapodagrionidae sp. were $76 \%$ of all the Odonata sampled individuals (17 specimens). There was not a preferred habitat type for the dominant taxa, despite the fact that Megapodagrionidae sp. was predominantly found in pool litter.

Hemiptera: Six Hemiptera genera were recorded. The hemipterans were relatively rare in samples, with few individuals being collected throughout our study period. The fact that many genera found in this study were not benthic may have contributed to these results. The genus Rhagovelia (Vellidae) was dominant on the three sampling occasions. Its dominance was $78 \%$ (of a total of 45 individuals in April), 81\% (from 72 individuals in August) and 79\% (from 52 individuals in February). The depositional areas (pool litter and sediment) were preferred by Rhagovelia at the fourth river order site $-\mathrm{S} 3$.

Diptera: Thirteen taxa were found. Dipterans were very abundant throughout the study period and in all sampling sites. The subfamily Orthocladiinae was dominant throughout the whole study period, with 58.40\% in April(from 3,502 dipterans); $45.02 \%$ in August (from 4,747 dipterans) and $50.26 \%$ in February (from 4,158 individuals). Despite the great abundance, Orthocladiinae was the dominant taxon on stone $(82.47 \%)$, riffle litter $(93.59 \%)$ and sediment $(87.5 \%)$, while Chironominae was predominant in pool litter $(51.46 \%)$.

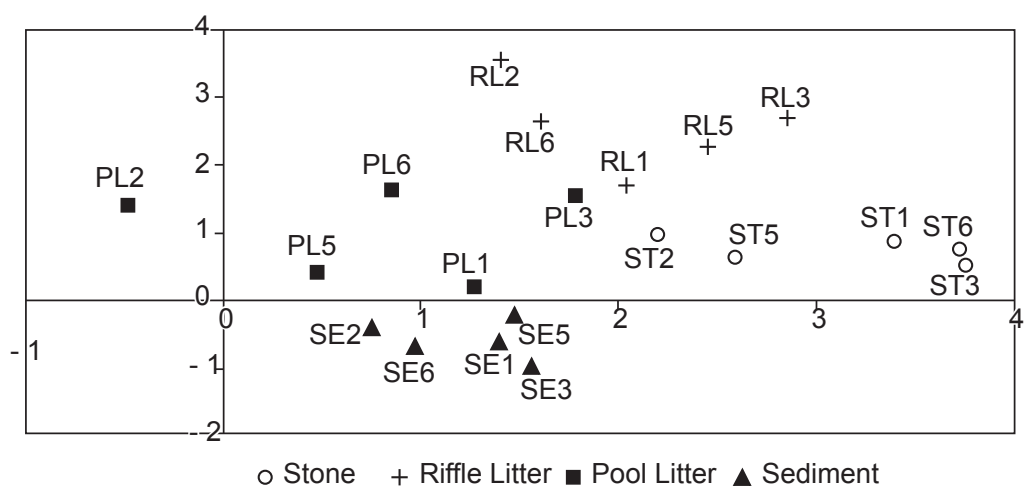

Fig. 3 - Detrended Correspondence Analysis for sites and substrates collected in the Sana river. Eigenvalues: Axis $1=18.05 \%$; Axis $2=11.24 \%$. ST-Stone; RL - Riffle Litter; PL - Pool Litter; and SE - Sediment. 


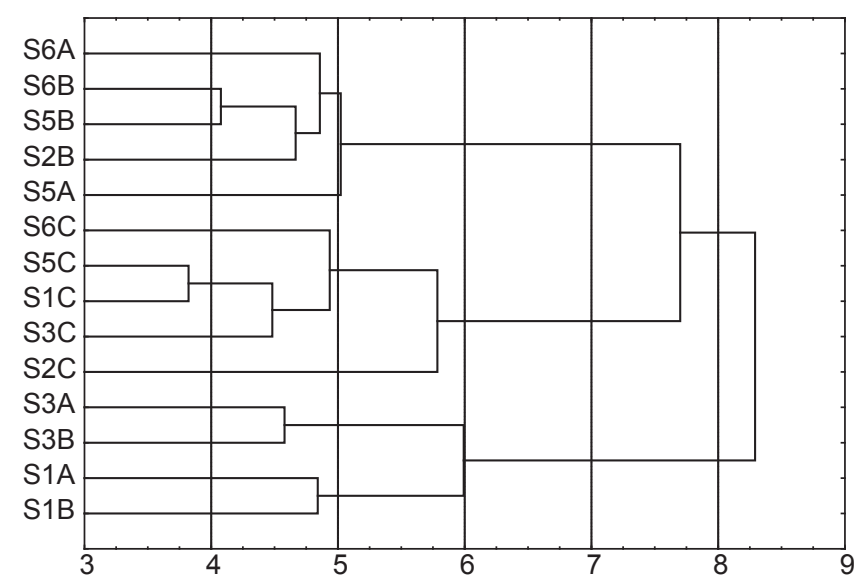

Fig. 4 - Cluster Analysis based on the abundance matrix (Ward's method). A - April; B - August; C - February.

\section{DISCUSSION}

In this study, the highest total richness and abundance were observed at the riffle litter substrate. This has been reported in many fast-flowing streams with similar stream-beds (Logan \& Brooker, 1983; Brown \& Brussock, 1991) and seems to be a general pattern in the Atlantic Forest streams (Baptista et al., 2001; Kikuchi \& Uieda, 1998). Rocky streambed areas are likely to have higher environmental stability and spatial heterogeneity, which may offer better conditions for fauna colonization (Death \& Winterbourn, 1995.

According to the DCA, substrate type was the most important factor in structuring macroinvertebrate assemblages in this study. These results corroborate other studies that state that the suitability of a substrate is a primary factor governing colonization by benthic invertebrates (Hynes, 1970; Minshall \& Minshall, 1977; Buss et al., 2004).

Cluster Analysis in sampling sites data showed the importance of temporal variation. The macroinvertebrate assemblage found in the wet season (February) was markedly different from the ones found in the other sampling seasons (April and August). The high precipitation observed in February increased the flow discharge and increased stream instability altering the community structure.

The separation of the $4^{\text {th }}$ (site S3) and $5^{\text {th }}$ (site $\mathrm{S} 1$ ) river order sections is another factor to be considered when developing a sampling program. Despite the absence of a great altitude gradient in our study area, this separation could be related to the transition zone described by the CCR model or by different hydraulic conditions resulting in a different community structure, as observed by Baptista et al. (2001), in another region of the Macaé river basin. Season is an abiotic parameter with great influence in macrobenthic community changes (Robinson \& Minshall, 1986). In tropical streams, the precipitation plays this important role for changes in the benthic community structure.

According to the physiographic index used (Habitat Assessment Field Data Sheet - High Gradient Streams), all sites were considered as reference ones. In spite of this, the small numerical contribution of shredders to the invertebrate assemblage reflects the intense deforestation process at the study area. Therefore, we suggest that adaptations of environmental indices are needed to reflect the real situation of this study area more accurately.

Collector-filterers comprised most of the FFG distribution, which can be explained by the most abundant taxa (subfamilies Chironominae, Orthocladinae and family Simulidae). Their great capacity of rapid colonization and tolerance to anthropogenic disturbances (siltation - Chironominae, Tanypodinae - and organic pollution) enables all the substrates to occupy throughout the whole year. The large proportion of collector-gathers (mainly Orthocladinae and Smicridea) at S1 is probably due to its great mean flow discharge, which is characteristic of this site as a lowland river as it has a considerable amount of fine particulate organic matter. The CCR model (Vannote, 1980) says that the taxonomic richness 
would be greater at middle reaches $\left(4^{\text {th }}\right.$ to $6^{\text {th }}$ river orders), as recorded by Baptista et al. (2001), in another region of the Macaé river watershed. Despite this, our results presented the maximum richness value at the $3^{\text {rd }}$ river order $(\mathrm{S} 2)$. On the other hand, the model also says that the shredders frequency would be bigger at upper reaches, which corroborates with our results, where site 3 ( $3^{\text {rd }}$ order $)$ presented the maximum shredder percentage, mainly due to the well preserved riparian forest at this site. Furthermore, the frequency of scrapers increased until site $\mathrm{S} 5$ ( $5^{\text {th }}$ order) corroborating with the CCR model. The highest values for diversity and evenness at middle reaches ( $4^{\text {th }}$ river order) are compatible with what was expected from the CCR model (Vannote et al., 1980), and also with results found elsewhere (Baptista et al, 2001).

The Ephemeroptera and Trichoptera were equally distributed throughout all the substrate types, with the exception of sediment. The greater richness numbers found for these aquatic insects may have contributed to this large distribution, together with less restrictive physiological requirements of some taxa (Smicridea and Baetidae, for example). Brown \& Brussock (1991) also stated a non-preference for mayfly habitats, which could be attributed to their adaptation to a wide range of current speeds and stream habitats. Considering the principal insect orders evaluated for substrate distribution, only Plecoptera presented a strong concentration in the riffle litter. This is not unexpected as this order is well known for requiring very aerated microhabitats (clean water with high dissolved oxygen and low siltation), which are easily found in riffle areas. The coleopterans did not show a substrate preference, but their frequency was somewhat concentrated in the riffle litter. These results are corroborated by Buss et al. (2002), where the distribution of plecopterans and elmid beetles was restricted to riffle areas due to the nearly saturated dissolved oxygen and shallow, fast flowing or cold streams. These demands are intrinsically related to physiological adaptations, such as the sensitive gills of Plecoptera and plastron respiration of Elmidae. In the present study, the dominating elmid genus was Heterelmis, concentrated at riffle areas (stone and riffle litter), contrasting with Brown \& Brussock (1991), who observed a higher density of this genus in pools. Skoroszewski \& de Moor (1999) found that the preferred habitat for many taxa (Elmidae, Simulidae, Hydropsychidae, Baetidae, Leptophlebidae, Perlidae) was cobble, associated with a medium to high flow speed. The exceptions were Vellidae and Oligochaeta, who preferred pool areas near to fringing vegetation and low current velocities. These records are compatible with our results, where Rhagovelia (Vellidae) and Oligochaeta preferred pool areas (pool litter), while many Elmidae, Baetidae, Perlidae, Grypopterygidae and Hydropsychidae genera were more restricted to riffle areas.

There was no benthic taxon which appeared exclusively on sediment substrates. McCulloch, (1986) who studied sandy substrates, stated that the instability of this substrate was a limiting factor for the benthos colonization. Other studies reported reduced densities and diversity in sandy and heavily silted streams (Hynes, 1970; Reger \& Kerven, 1981).

The Rapid Bioassessment Protocols are being applied in many countries with success, optimizing time and resources in sample methodologies. Unfortunately, in developing countries like Brazil, and especially in the Atlantic Forest region, there is a lack of basic knowledge on taxonomics and distribution patterns for benthic macroinvertebrates. Thus, more studies based on sampling of different microhabitats and substrates are needed to understand the tropical benthic community structure better. Afterwards, we will probably be able to adapt and develop our own biotic indices and many other important metrics for water quality evaluation.

Acknowledgments - The authors are grateful to MSc. Juliana Assis (UFRJ), MSc. Maria Inês Passos (UFRJ) MSc. Ana Lúcia Henriques (UFRJ) and MSc. Frederico Falcão for identifying the specimens of Odonata, Coleoptera, Diptera and Ephemeroptera, respectively. We are also grateful to PhD. Aline Holanda Nunes Maia (Embrapa Environment) for the statistical analysis contribution. This paper is based in part on a dissertation by M. P. Silveira (PPGE/UFRJ). Partial funding was provided by Fiocruz and CNPq.

\section{REFERENCES}

ANGRISANO, E. B., 1995, Insecta Trichoptera, pp. 1199-1237. In: E. C. LOPRETTO \& G. TELL (eds.), Ecossistemas de Aguas Continentales: metodologias para su estudio, $3^{\circ}$ vol., Ediciones Sur, La Plata, Argentina.

BAPTISTA, D. F., DORVILlÉ, L. F. M., BUSS, D. F. \& NESSIMIAN, J. L., 2001, Spatial and temporal organization of aquatic insects assemblages in the longitudinal gradient of a tropical river. Revista Brasileira de Biologia, 61(2): 295-304. 
BARBOUR, M. T., GERRITSEN, J., SNYDER, B. D., \& STRIBLING, J. B., 1999, Rapid Bioassessment Protocols for Use in Streams and Wadeable Rivers: Periphyton, Benthic Macroinvertebrates and Fish, Second Edition. EPA 841-B-99-002. U.S. Environmental Protection Agency; Office of Water; Washington, D.C.

BRETSCHKO, G. \& MOSER, H., 1993, Transport and retention of matter in riparian ecotones. Hydrobiologia, 251: 95-101.

BROWN, A. V. \& BRUSSOCK, P. P., 1991, Comparisons of benthic invertebrates between riffles and pools. Hydrobiologia, 220: 99-108.

BRUNS, D. A., MINSHALl, G. W., CUSHING, C. E., CUMMINS, K. W., BROCK, J. T., \& VANNOTE, R. L, 1984, Tributaries as modifiers of the river continuum concept: Analysis by polar ordination and regression models. Archiv fur Hydrobiologie, 99(2): 160-175.

BUSS, D. F., BAPTISTA, D. F., SILVEIRA, M. P., NESSIMIAN, J. L. \& DORVILLÉ, L. F. M., 2002, Influence of water chemistry and environmental degradation on macroinvertebrate assemblages in a river basin in southeast Brazil. Hydrobiologia, 481: 125-136.

BUSS, D. F., BAPTISTA, D. F., NESSIMIAN, J. L. \& EGLER, M. 2004. Substrate specificity, environmental degradation and disturbance structuring macroinvertebrate assemblages in neotropical streams. Hydrobiologia, 518(1): 179-188.

CARVAlHO, A. L. \& CALIL, E. R., 2000, Chaves de identificação para as famílias de Odonata (Insecta) ocorrentes no Brasil, adultos e larvas. Papéis Avulsos de Zoologia, 41(15): 223-241.

DEATH, R. G. \& WINTERBOURN, M. J., 1995, Diversity patterns in stream benthic invertebrate communities: the influence of habitat stability. Ecology, 76(5): 1446-1460.

FERNÁNDEZ, H. R. \& DOMÍNGUEZ, E., 2001, Guía para la determinación de los Artrópodos Bentónicos Sudamericanos. Editora Universitária de Tucumán, 282p.

GREGORY, S. V., SWANSON, F. J., MCKEE, W. A., \& CUMMINS, K. W., 1991, An ecosystem perspective of riparian zones: Focus on links between land and water. Bioscience, 41: 540-551.

HYNES, H. B. N., 1970, The Ecology of Running Waters. Univ. of Toronto Press, Canada, 555p.

JOWETT, I. G., 1997, Instream flow methods: a comparison of approaches. Regulated Rivers: Research and Management, 13: 115-127.

KIKUCHI, R. M. \& UIEDA V. S., 1998, Composição da comunidade de invertebrados de um ambiente lótico tropical e sua variação espacial e temporal, pp. 157-173, In: J. L. Nessimian \& A. L. Carvalho (Eds.). Ecologia de Insetos Aquáticos. Séries Oecologia Brasiliensis, $5^{\circ}$ vol., PPGE-UFRJ. Rio de Janeiro, Brasil.

LOGAN, P. \& BROOKER, M. P., 1983. The macroinvertebrate faunas of riffle and pools. Water Research, 17(3): 263-270.
McCULLOCH, D. L., 1986, Benthic macroinvertebrate distribution in the riffle-pool communities of two east Texas streams. Hydrobiologia, 55: 61-70.

MERRITT, R. W. \& CUMMINS, K. W. (eds.), 1996, An introduction to the Aquatic Insects of North America, $3^{\text {rd }}$ ed. Kendall/Hunt Publishing, Dubuque, IA. 862p.

MINSHALL, G. W. \& MINSHALL, J. N., 1977, Microdistribution of benthic invertebrates in a rocky mountain (USA) stream. Hydrobiologia, 55(3): 231-249.

NAIMAN, R. J., DÉCAMPS, H., PASTOR, J. \& JOHNSTON, C. A., 1988, The potential importance of boundaries to fluvial ecosystems. Journal of the North American Benthological Society, 7: 289-306.

NIESER, N. \& DE MELO, A. L., 1997, Os heterópteros aquáticos de Minas Gerais. Editora UFMG, Belo Horizonte, 180p.

PARSONS, T. R., MAITA, Y. \& LALLI, C. M., 1984, A Manual of Chemical and Biological Methods for Seawater Analysis. Pergamon Press, Oxford, 173p.

REGER, S. J. \& KEVERN, N. R. 1981, Benthic macroinvertebrate diversity in three Michigan streams. $J$. Freshwat. Ecol., 1: 179-187.

RESH, V. H., BROWN, A. V., COVICH, A. P., GURTZ, M. E., LI, H. G., MINSHALL, G. W., REICE, S. R., SHELDON, A. L., WALLACE, J. B. \& WISSMAR, R. C., 1988, The role of disturbance in stream ecology. Journal of the North American Benthological Society, 7: 433-455.

ROBINSON, C. T. \& MINSHALL, G. W., 1986, Effects of disturbance frequency on stream benthic community structure in relation to canopy cover and season. Journal of the North American Benthological Society, 5: 237-248.

SKOROSZEWSKI R. \& DE MOOR, F., 1999, Specialist Report Macroinvertebrates. Consulting Services for the Establishment and Monitoring of the Instream Flow Requirements for River Courses Downstream of LHWP Dams. Cape Town. 104p. Disponível em: www. southernwaters.co.za/lhda/648-f-17.pdf.

STATZNER, B., GORE, J. A. \& RESH, V. H., 1988, Hydraulic stream ecology: Observed patterns and potential applications. Journal of the North American Benthological Society, 7: 307-360.

TOWNSEND, C. R., ABRUCKLE, C. J., CROWL, T. A. and SCARSBROOK, M. R., 1997, the relationship between land use and physicochemistry, food resources and macroinvertebrate communities in tributaries of the Taieri River, New Zealand: a hierarchically scaled approach. Freshwater Biology, 37: 177-191.

VANNOTE, R. L., MINSHALL, G. W., CUMMINS, K. W., SEDELL, J. R. \& CUSHING, C. E., 1980, the River Continuum Concept. Can. J. Fish. Aquat. Sci., 37: 130-137.

WALLACE, J. B. \& WEBSTER, J. R., 1996, The role of macroinvertebrates in stream ecosystem function. Annиal Review of Entomology, 41: 115-139. 